\title{
THE IMPORTANCE OF THERMAL COMFORT IN DIFFERENT ELEVATION FOR CITY PLANNING
}

\author{
S. YILMAZ ${ }^{1, *}$ \\ M. AKIF IRMAK ${ }^{2}$ \\ A. MATZARAKIS ${ }^{3}$
}

\author{
${ }^{1}$ Ataturk Univ., Fac. of Architecture and Design \\ Dept. of Landscape Architecture \\ 25240, Erzurum, Turkey \\ ${ }^{2}$ Albert-Ludwigs University of Freiburg \\ Werthmann str. 10, D- 79085 Freiburg, Germany
}

Received: $20 / 03 / 13$

Accepted: 25/04/13 *to whom all correspondence should be addressed: e-mail: syilmaz68@hotmail.com; sevgiy@atauni.edu.tr

\section{ABSTRACT}

This study investigates the thermal and bioclimatic conditions in Erzurum plain and the nearby Palandoken Mountains. The data was obtained from Erzurum Meteorological Station (1758 m) and Palandoken Mountains Meteorological Station (2973 m) for 2009 and 2010 in order to compute physiologically equivalent temperatures (PET). The results indicated that the average annual PET value for Erzurum was $-0.3{ }^{\circ} \mathrm{C}$ while the corresponding value was $-6.4{ }^{\circ} \mathrm{C}$ for the Palandoken Mountains. The difference between the two locations was $6.3 \stackrel{\circ}{\circ} \mathrm{C}$ for 2009 and $5.9 \stackrel{\circ}{ } \mathrm{C}$ for 2010 . During the summer months of 2009 , the PET difference was $7.4{ }^{\circ} \mathrm{C}$ while the corresponding difference was $6.4^{\circ} \mathrm{C}$ for 2010. During the winter months of 2009 , the PET difference was $3.1 \stackrel{\circ}{\circ} \mathrm{C}$ while the corresponding difference was $3.7^{\circ} \mathrm{C}$ for 2010 . It was determined that the $1179 \mathrm{~m}$ elevation difference between the two stations resulted in PET declines of $0.5 \stackrel{\circ}{ } \mathrm{C}$ for each $100 \mathrm{~m}$. It was also observed that during days when the temperature is extremely low, due to the movement of cold spots to lower elevations, the PET values in Erzurum were observed to be lower than the ones in Palandoken mountains that are located only $13.5 \mathrm{~km}$ north-east of the city.

KEYWORDS: PET, thermal comfort, Erzurum, Palandoken Mountains, planning.

\section{INTRODUCTION}

It is desirable that living areas should be comfortable, free of annoyances, and energy efficient. Environmental problems related to heating issues are frequently faced especially in areas with harsh climates (Toy, 2010). To minimize these adverse effects and to use the energy sources in a controlled way, one needs to start with the correct location selection when designing new settlement areas. The topographical characteristics of a location will certainly affect the design process the life styles of individuals who settle there (Anderson, 2000). Of course, the climatic factors affected by the topography will eventually influence the way people live in these areas. The physical environment will influence the activities of humans living there. Among the physical factors, probably the climate is the most important one. It affects the way people dress, where they live, what they produce, the types of industries that develop, and the architectural structures that are developed (Anderson, 2000; Kolawole, 2001; Gaitani et al., 2007). A growing public awareness of the negative environmental impacts of human actions in the past three decades (Ndubisi, 2003).

Population movements into the areas investigated in this study requires that new building complexes must be planned. These new living areas have been moving towards the Erzurum plain with rich agricultural land resources. Thus, there is a move of new settlements from the historical city center towards the low lying areas of Palandoken Mountains. Meanwhile, attempts continue to revive the old city.

The climate has been getting warmer with increasing temperatures especially in the urban centers (IPPC, 2007; Bates et al., 2008). To minimize the impact of this trend, one needs to consider the characteristics of the area before new construction projects are planned. In fact, the 1939 study that 
was conducted by city planner $\mathrm{J}$. Lambert is discussed now once again as the Erzurum city center is re-designed. At this stage, the severe weather conditions in Erzurum where minimum elevation is $1850 \mathrm{~m}$, the planners should note the air pollution caused by heating systems during winter months and consider natural gas heating systems. A recent study (Johansson, 2006), has investigated the geometric make up of the city streets by measuring thermal comfort during hot summer and cold winter months in wide and narrow streets.

The main objective of landscape architecture is to create comfortable living spaces for the inhabitants. Thus, urban restructuring projects need to consider the climate and thermal comfort conditions. Such projects should include the most comfortable bioclimatic values in designing the parks, wooded areas, streets, pavements, squares, and recreational areas. If the thermal comfort criteria are fully used, ideal living areas can be created for the inhabitants. From 1905 to the present time, about 40 different thermal comfort indexes have been developed (Epstein and Moran, 2006). One can classify these into two categories. Simple indexes that take two or more climatic elements into account (such as THI, ET) fall under the first category. In this index, THI is used very commonly before PET (Unger, 1999; Yilmaz et al., 2007a; Yilmaz et al., 2007b). Under the second category, there are the complex indices inclusive human characteristics (such as the clothing that they wear) together with climatic factors. Such indexes include PMV (Predicted Mean Vote; Fanger, 1970), PET (Physiologically Equivalent Temperature; Höppe, 1999), and SET* (New Standard Effective Temperature; Gagge et al., 1971). All of these indexes provide a single bioclimatic value and naturally the computed value depends on the type and number of variables used in the formulation.

During the recent years, PET index has been often used to determine the optimal climatic level that provides humans with the most comfortable environment. PET computations suggest that this comfort interval is between 18.1 and $23.0^{\circ} \mathrm{C}$ and it is based on a complete budget model for the human body (Table 1) (Fanger, 1970; Mayer and Höppe, 1987; Höppe, 1999; Matzarakis and Amelung, 2008). A review literature indicates that there are lots of academic studies that are based on PET. These include temporal and spatial studies (Matzarakis and Gulyas, 2007; Scott et al., 2006; Thorsson et al., 2011), urban open area and park studies (Picot, 2004; Nikolopoulou and Lykoudis, 2006; 2007; Toy and Yilmaz, 2010; Lin et al., 2012; Fröhlich and Matzarakis, 2012), studies on urban squares, streets and avenues (Givoni et al., 2003; Johansson, 2006; Ali-Toudert and Mayer, 2007a; Ali-Toudert and Mayer, 2007b; Lin, 2009), studies that aim determining the optimal vegetation types that effect comfort (Cohen et al., 2012), studies conducted near rivers, lakes, and seas (Farajzadeh and Matzarakis, 2012), studies that focus on a variety of mountainous areas (Kamoutsis et al., 2010; Chronopoulos et al., 2012a), and comfort determination studies on recreational touristic sites ((Scott et al., 2004; Hamilton and Lau, 2004; Matzarakis and Rutz, 2005; Rudel et al., 2007; Lin and Matzarakis, 2008; 2011; Mishev and Mochurova, 2008; Perch-Nielsen, 2008; Zaninovic and Matzarakis, 2009; Yilmaz et al., 2009; Matzarakis et al., 2012). Another study focused into the impact of green areas on the climate of the urban centers (Zhang et al., 2009).

The differences in the topographic structures have an impact on the climate and climatic changes have a direct impact on human life. There have been studies that included topographic structures in determining thermal comfort levels (Zaninovic et al., 2006; Endler et al., 2010; Kamoutsis et al., 2010; Caliskan et al., 2013). Other studies have focused at role of altitude as well as the orientation in determining comfort levels (Chronopoulos et al., 2012b). Zhao et al., (2011) have made an attempt to determine the role of varying morphological structures on climate and they have emphasized the importance of this factor for city planning.

In recent years, in spite of the increase in the number of studies related to the PET, there is still limited number of studies made in cold climate region of Turkey such as East Anatolia. In Erzurum which is subjected to the rapid immigration, urbanization, and urban transformation projects in the last decade, definition of the comfort level become very crucial. It is because the agricultural areas in the west and north side of the city is started to be used as new settlement areas.

In order to make a contribution towards the urban restructuring projects, this study investigated the thermal comfort levels at the highest mountain in Erzurum, Palandoken Mountain $(3170 \mathrm{~m})$ and the lowest level in Erzurum plain $(1850 \mathrm{~m})$. The objective was to assess the impact of topographical structure on thermal comfort. In both locations, there are State Meteorological Stations from which steady data can be obtained. However, the station in Palandoken Mountain has been recently established and only 2009-2010 data was available from them. Thus, only 2009 and 2010 climatic information was used to determine the bioclimatic comfort conditions in both stations to compare and quantify the vertical bioclimatic comfort difference using PET. 


\section{Stations and Methodology Data and Study Area}

The location of the measurement stations for the data used in this study is shown in Figure 1. The State Meteorological station in the Erzurum plain has been around for a long time while station in Palandoken Mountain has been established only a few years ago and hence no historical data. Thus, this study that compares thermal comfort in these two areas is based on 2009 and 2010 data. Erzurum is located in eastern Turkey and has an altitude of 1850 meters. In the city, a harsh continental climate is prevalent with long and extremely cold winters.

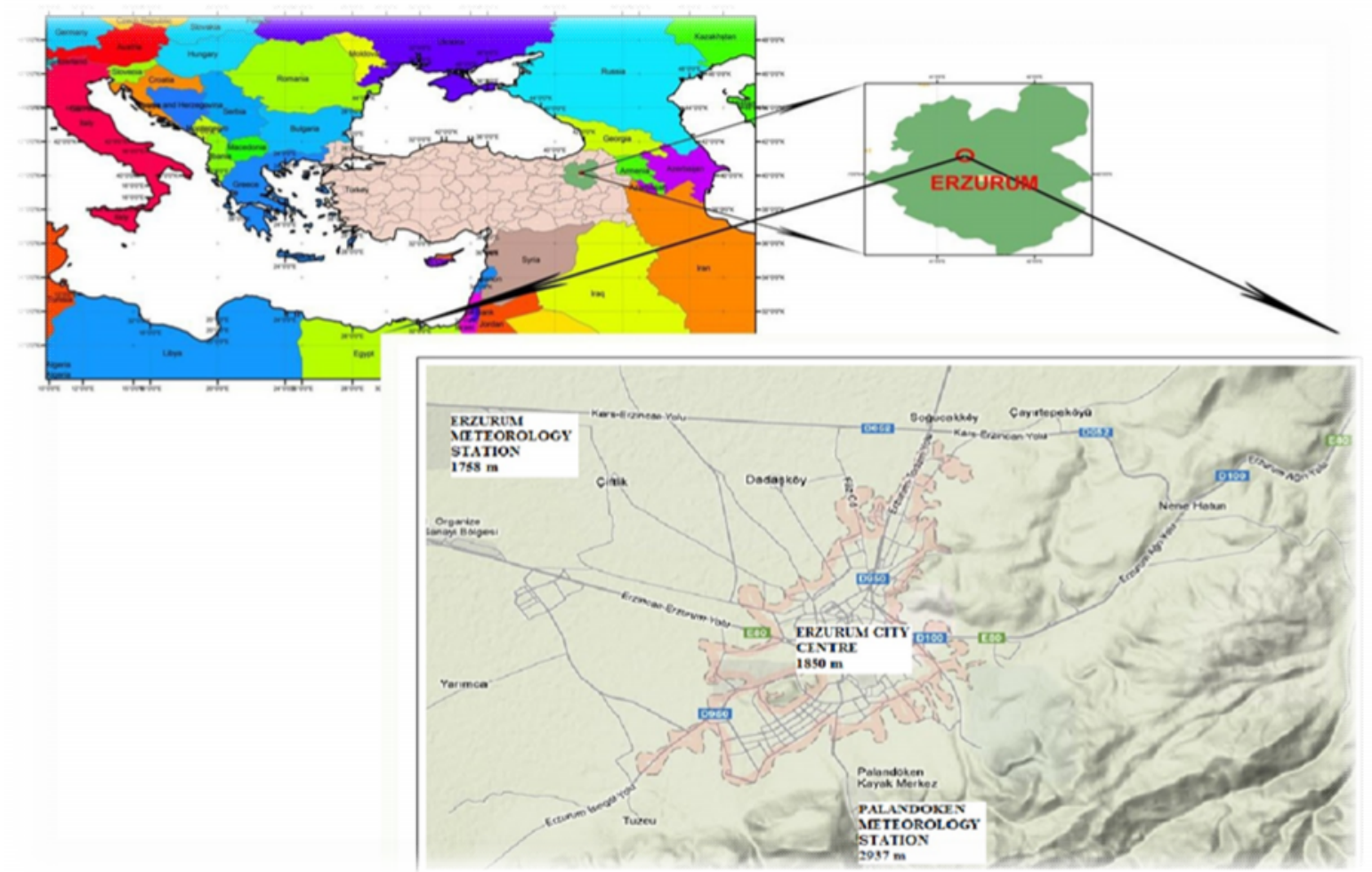

Figure 1. The locations of Erzurum Plain and Palandoken Mountains Meteorological (Google Maps, 2012, http://maps.google.com/)

Meteorological observations have been carried out since 1929 in the city. Erzurum Plain meteorological station was surrounded by the rural area and established in the airbase area in 1988 . This station (at an elevation of $1758 \mathrm{~m}$ and a location of $39^{\circ} 57^{\prime} \mathrm{N}$ and $41^{\circ} 10^{\prime} \mathrm{E}$ ), considered as the representative of a rural area, is in the Airbase area lying about $7 \mathrm{~km}$ from the city. The Airbase is surrounded by the vast open area in all directions. There are no buildings or human activities around the station except for the cultivated area which is $4 \mathrm{~km}$ from the station and where plants that do not need watering are grown.

Palandoken meteorological station was established in new, but regular data collection has been started recently, for only a few years. The coordinates of the station in where data were collected are $39^{\circ} 48^{\prime} 32^{\prime \prime} \mathrm{E} ; 41^{\circ} 17^{\prime} 41^{\prime} \mathrm{N}$, and the altitude is $2937 \mathrm{~m}$. Thermal comfort and PET evaluations were performed on data for 2009 and 2010 provided from the Turkish State Meteorological Service, Electronic Data Process Center Division. Palandoken ski area is located $6 \mathrm{~km}$ away from the city center, $4 \mathrm{~km}$ away from the newly established Yenisehir district and $15 \mathrm{~km}$ from the airport. The altitude varies from 2200 to $3176 \mathrm{~m}$ in Palandoken Mountain that consists of many hill slopes. The Great Ejder, the highest point of Palandoken mountain, is $3188 \mathrm{~m}$ high. The range of Palandoken mountain is about $72 \mathrm{~km}$. Palandoken mountain is among the foremost and privileged ski-centers in point of winter tourism and winter sports in Turkey, has conveyed the features of the international main station for winter activities (Figure 2). With this feature, it constitutes the most significant part of the city tourism sector. There are two main ski runs; the south ski run is $8 \mathrm{~km}$ long and the north ski run is devised for the advanced skiers. $t$ is possible to ski on Great Ejder (2200-3100m) and 
possible to reach $3100 \mathrm{~m}$. by chair lift is $3237 \mathrm{~m}$. long and can carry 360 people per hour (http://images.google.com).

In this region, on the average the first snow of the year falls in late October and snow remains on the ground until July. Recently, a significant amount of investments have been made in the area because the city hosted 2011 university winter Olympics.

\section{METHODS}

\section{Thermal Comfort Calculation}

The aim of this study is to determine the distribution of human thermal comfort conditions in Palandoken Months and Erzurum Plain using a very popular bioclimatic comfort index PET (Physiologically Equivalent Temperature) and calculation model, RayMan (Matzarakis et al., 2007; 2010). The basis of the index is the acceptation of the felt human heat balance under light workload in an indoor places as equal to the real external environment. Physiologically Equivalent Temperature (PET) Index deal with the thermal conditions according to physiological approach (Höppe, 1999; Matzarakis et al., 1999). The main idea of the PET is the transfer of the real indoor thermal bioclimatic conditions to the speculative/fictive outdoor place in which creation of the same effects is expected (Mayer, 1993). PET Index also includes the heat transmission resistance of the clothes and metabolic, heat generation. On the other hand, as one of the model used for the calculation of PET, The RayMan Model developed according to Guideline 3787 of the German Engineering Society is used in the context of this study. This model calculates the radiation flux in simple and complex environments (VDI, 1998). In this model, thermal sensation is calculated by adapting the following constants; body surface is standardized to $1.9 \mathrm{~m}^{2}$; a height of $1.75 \mathrm{~m}$; and a body weight of $75 \mathrm{~kg}$ (Mayer and Höppe, 1987).

In order to computer PET using the RayMan model, the following types of data are needed: air temperature $\left(\mathrm{Ta},{ }^{\circ} \mathrm{C}\right)$, Mean radiant temperature is equal to air temperature (Tmrt $=\mathrm{Ta}$ ), humidity $(\mathrm{RH}, \%)$, wind speed (WS, $\mathrm{m} / \mathrm{s})$, degree of cloud cover (octas) or global radiation $\left(\mathrm{Gr}, \mathrm{W} / \mathrm{m}^{2}\right)$ values. Enviromental features of the imaginary indoor place in which comfort values are calculated; It is stated that Tmrt $=\mathrm{Ta}, \mathrm{v}=0,1 \mathrm{~m} / \mathrm{s}$ and $\mathrm{VP}=12,0 \mathrm{hPa}$. Tmrt is the indicator of the mean radiant temperature; $\mathrm{Ta}$ is equal to the air temperature; $\mathrm{V}$ is the value of air (wind) speed; and VP is the Water vapor pressure. The result of PET Index is calculated as ${ }^{\circ} \mathrm{C}$ (Mayer and Höppe, 1987; Höppe, 1999), and for this reason, it provides information and perspectives for unrelated persons.

In the study, PET (Physiologically Equivalent Temperature) index was used to evaluate the comfort conditions of two years. Data from 2009 and 2010 were used to compute PET scores. For the computations RayMan Model can be used (e.g. Höppe, 1999; Matzarakis et al., 1999; 2007). The results were provided in Table 1. To show the location of the stations with respect to the center of Erzurum city, diagram/map and section was prepared and it is shown in Figures 2 and 3.

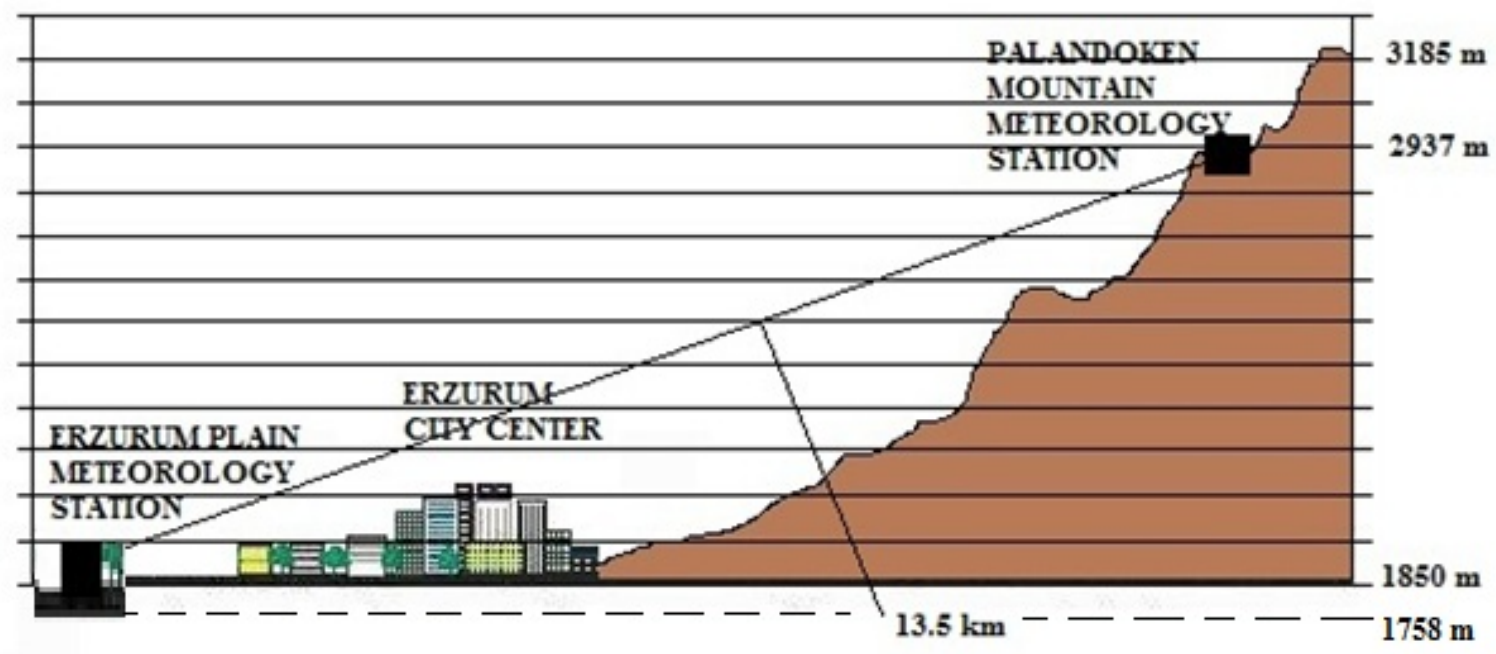

Figure 2. Diagram of Erzurum Plain and Palandoken Mountain with respect to city center 


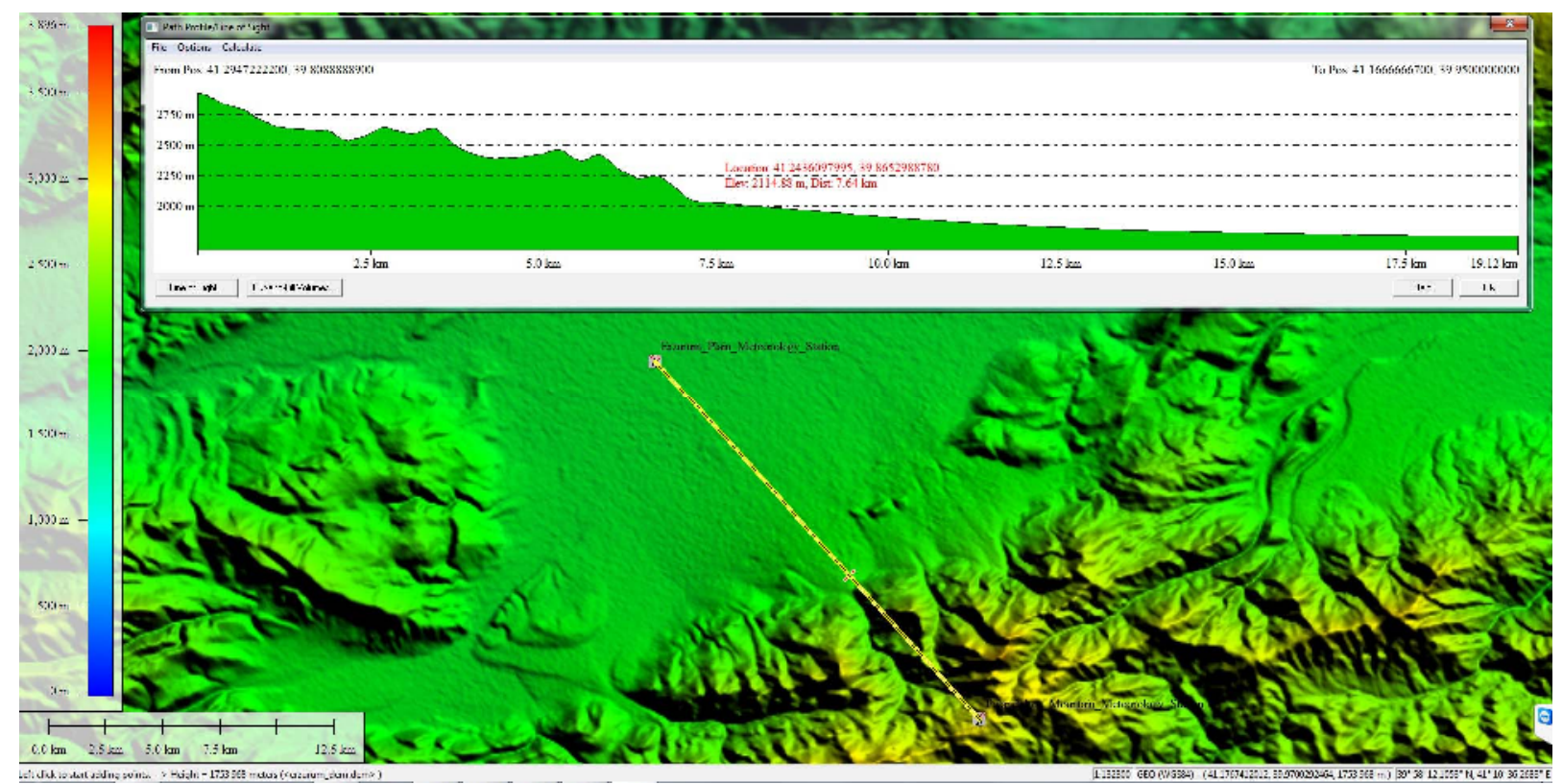

Figure 3. Plan view between two stations (It is obtained from the elevation model of the TUBITAK project numbered as 106Y130, http://www.tsym3.selcuk.edu.tr)

Palandoken Mountain is an important ski center in Turkey. The satellite pictures of the two stations that provided the data are provided in Figure 4. The city of Erzurum is built in location where the elevation ranges from 1850 to 2000 meters. It is one of the few cities in the world this kind of altitude.

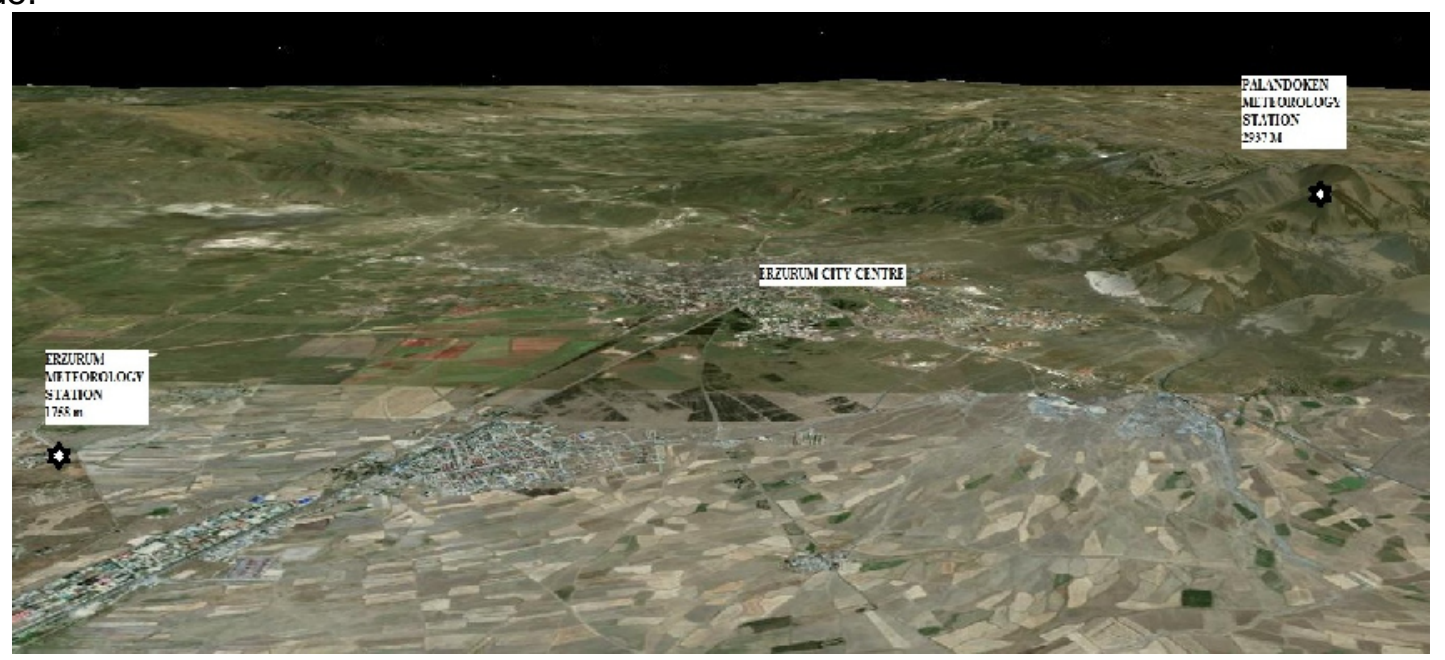

Figure 4. Erzurum Plain Meteorology Station, Erzurum City Center and Palandoken Mountain Meteorology Station (Google Earth, 2012, http://googlearth.com/)

\section{RESULTS}

The PET values computed for Erzurum plain and Palandoken Mountains are provided in Table 1 and they were interpreted using thermal comfort intervals.

Erzurum plain and Palandoken Mountain data for 2009 and 2010 were used to compute daily PET values (Figure 5). Between these two locations, significant and consistent PET value differences were observed for the summer months. With the exception of December and January, the daily PET value averages in Palandoken Mountains were found to be lower than those in Erzurum plain. The PET values show less consistency during December and January, and especially during inversion activity, the average PET values in the Mountain were higher than those in the plain. 
Table 1. PET index Comfort Intervals (Matzarakis et al., 1999)

\begin{tabular}{lll}
\hline PET $(-\mathbf{C})$ & Thermal perception & Grade of physiological stress \\
\hline$<4$ & Very cold & Extreme cold stress \\
$4.1-8.0$ & Cold & Strong cold stress \\
$8.1-13.0$ & Cool & Moderate cold stress \\
$13.1-18.0$ & Slightly cool & Slight cold stress \\
$18.1-23.0$ & Comfortable & No thermal stress \\
$23.1-29.0$ & Slightly warm & Slight heat stress \\
$29.1-35.0$ & Warm & Moderate heat stress \\
$35.1-41.0$ & Hot & Strong heat stress \\
$>41.0$ & Very hot & Extreme heat stress \\
\hline
\end{tabular}

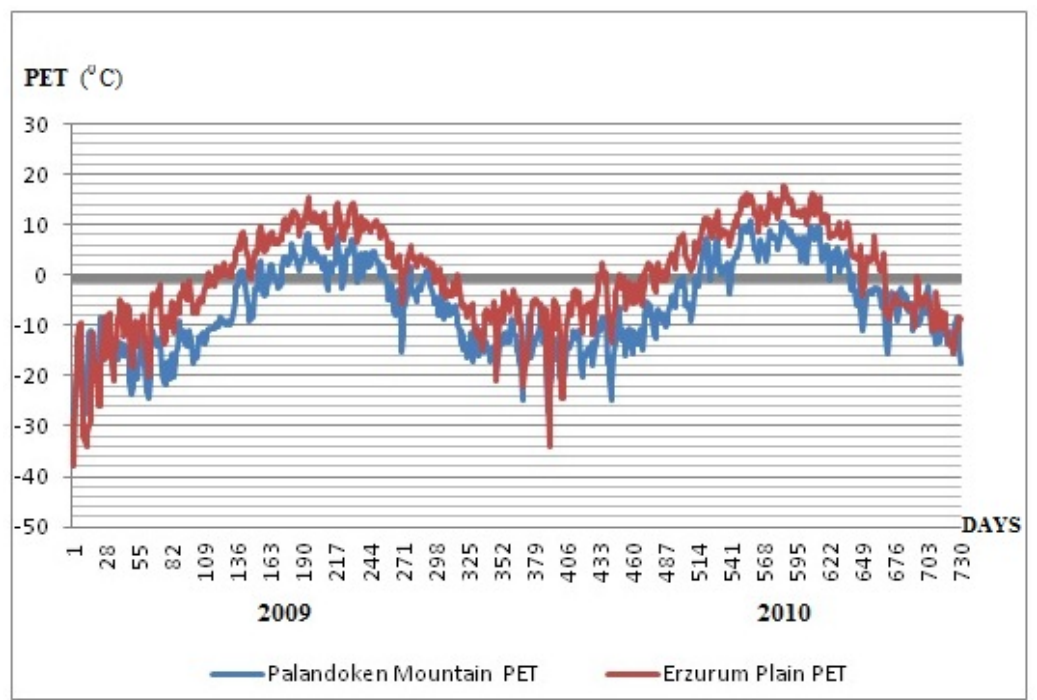

Figure 5. Average daily PET values in Erzurum plain and Palandoken Mountains during 2009 and 2010

Figure 6 shows the PET values for 2009 for the Mountain and the plain. For July and August, Erzurum plain shows moderate cold stress. During all other months, extreme cold stress and strong cold stress were observed. In 2009, for the entire year, Palandoken Mountain showed extreme cold stress and strong cold stress. The monthly distribution for 2010 is provided in Figure 7. Since 2010 was a relatively warm year all around the world, differences were observed compared to 2009. An examination of the graphs indicate that in 2009 the average January PET was below $-20 \stackrel{\circ}{\circ}$, the corresponding value was about $-10 \stackrel{\circ}{\mathrm{C}}$ (Figures 6 and 7 ).

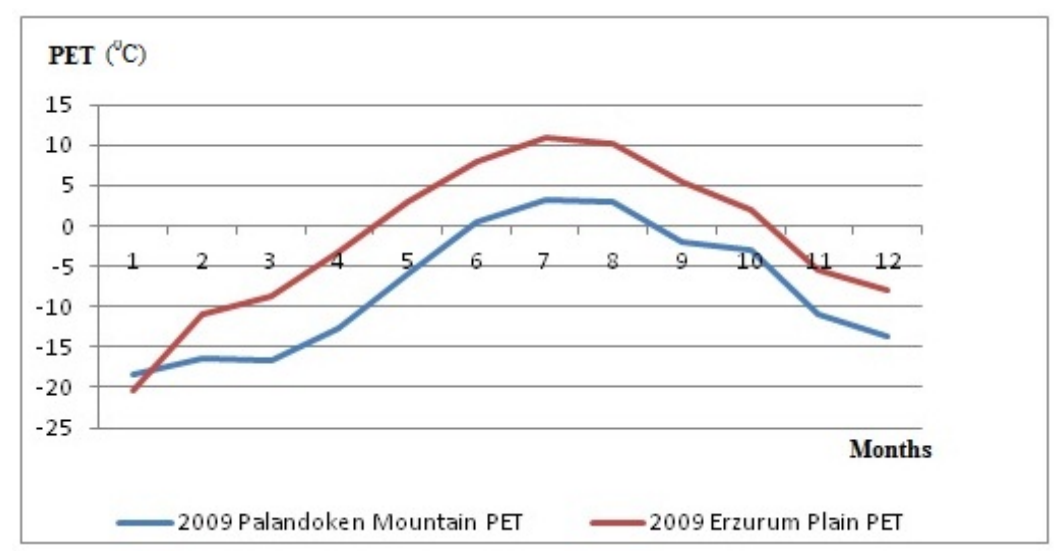

Figure 6. Average Monthly PET values in Erzurum Plain and Palandoken Mountain, during the year 2009 


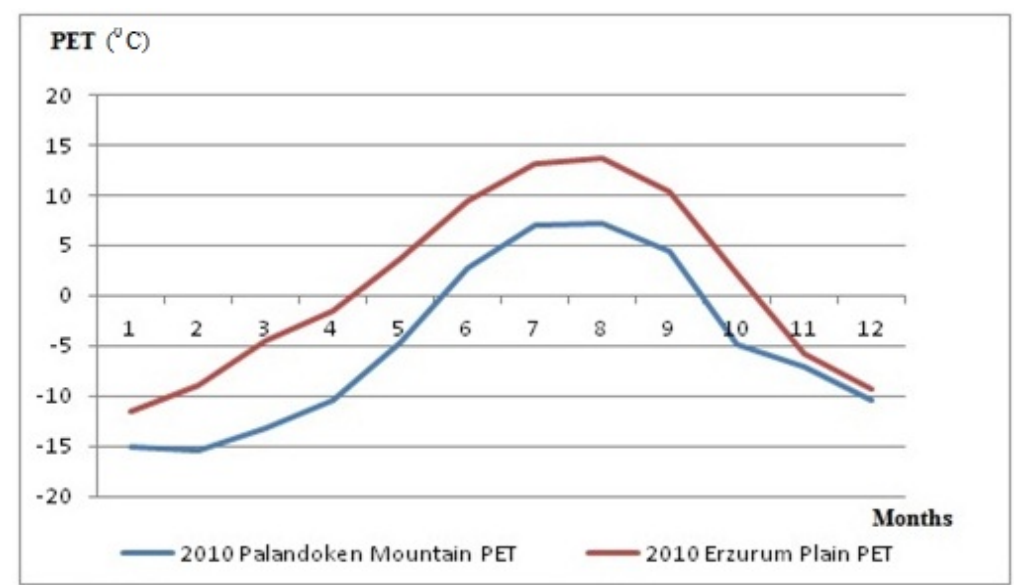

Figure 7. Average Monthly PET values in Erzurum Plain and Palandoken Mountain, during the year 2010

The mean annual PET values during the period of 1975-2010 for Erzurum province is provided in Figure 8. An examination of the distribution indicated that extreme cold stress conditions prevailed in the long run. The "cold" and "extreme cold" conditions start at the beginning of October and last until the end of April. The "comfortable" interval is only seen during summer months and "extremely hot" stress is not observed.

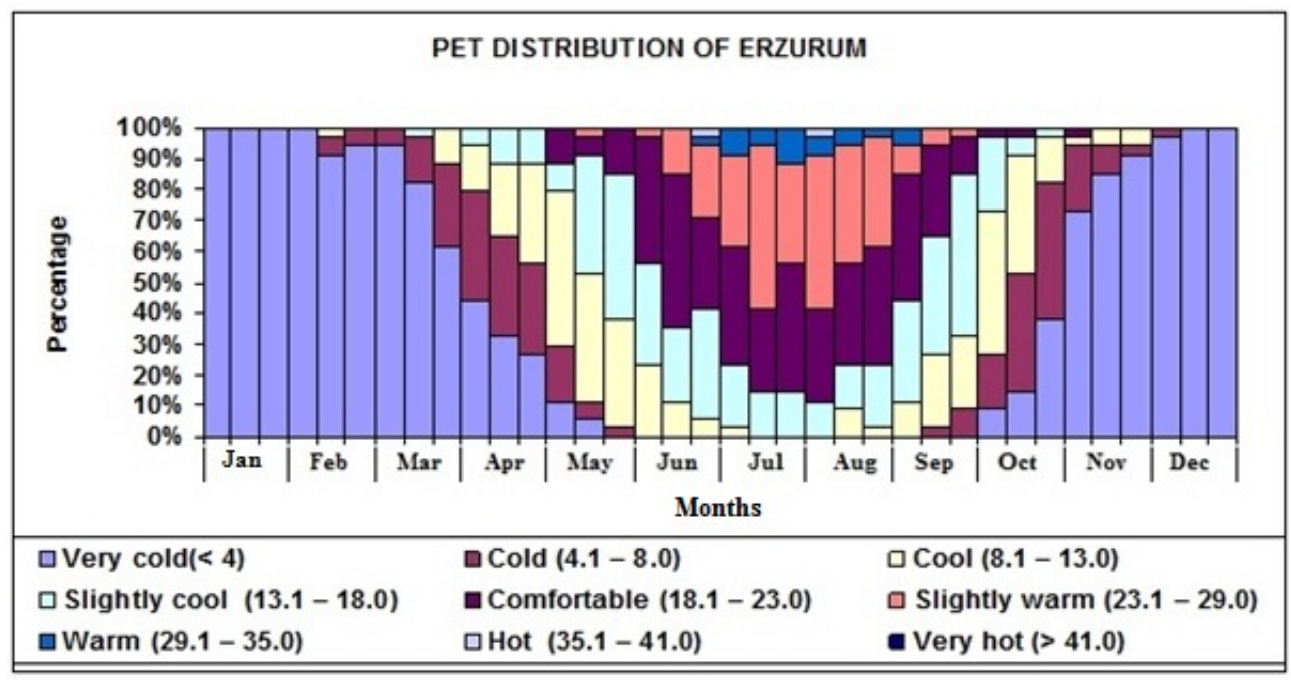

Figure 8. Distribution of PET Values for Erzurum (Toy et al., 2010; Yilmaz et al., 2010)

As can be observed in Table 2, in 2009, the average temperature in Palandoken Mountain was only $0.3^{\circ} \mathrm{C}$, the average PET values was computed to be $-7.8^{\circ} \mathrm{C}$. The corresponding figures for Erzurum plain were $5.8{ }^{\circ} \mathrm{C}$ for annual average temperature and $-1.5 \stackrel{\circ}{ } \mathrm{C}$ for PET value. In both areas in 2009 , when one considers the annual average PET values, "extreme cold" stress conditions were prevalent. An examination of the monthly PET averages, one can conclude that "extreme cold stress," "strong cold stress," and "moderate cold stress" conditions were prevailed.

In 2010, the average annual temperature in Palandoken Mountain was $2.8^{\circ} \mathrm{C}$ and the PET value was $-5.0 \stackrel{\circ}{\circ}$. The corresponding values in Erzurum plain were $7.9{ }^{\circ} \mathrm{C}$ for temperature and $0.9{ }^{\circ} \mathrm{C}$ for PET value. Both areas, like in 2009, showed "extreme cold stress" conditions. However, when one examines the 2010 monthly PET values, unlike 2009, Erzurum plain showed "slight cold stress" conditions in July and August while in all other months both areas showed "extreme cold stress," "strong cold stress," and "moderate cold stress" conditions. An examination of monthly PET averages for both regions (Table 3) indicates that for the 2009-2010 period, only in Erzurum plain in July and August of 2010, PET values indicated "slight cold stress" conditions while in all other months, "extreme cold," "strong cold," and "moderate cold" stress conditions were prevailed. 
Table 2. Various meteorological data about Palandoken Mountain and Erzurum Plain

\begin{tabular}{|c|c|c|c|c|c|c|c|c|c|c|c|c|c|}
\hline $\begin{array}{l}2009 \\
\text { Palandoken } \\
\text { Mountain }\end{array}$ & 1 & 2 & 3 & 4 & 5 & 6 & 7 & 8 & 9 & 10 & 11 & 12 & $\begin{array}{l}\text { Mean } \\
\text { year }\end{array}$ \\
\hline $\begin{array}{l}\text { Mean } \\
\text { temperature } \\
\left({ }^{\circ} \mathrm{C}\right)\end{array}$ & $-9,2$ & $-8,4$ & $-8,2$ & $-4,0$ & 2,2 & 8,0 & 10,7 & 10,5 & 5,8 & 4,8 & $-3,5$ & $-5,6$ & 0,3 \\
\hline $\begin{array}{l}\text { Mean wind } \\
\text { velosity }(\mathrm{m} / \mathrm{s})\end{array}$ & 6,7 & 4,7 & 5,5 & 6,4 & 5,0 & 5,2 & 4,7 & 4,6 & 5,0 & 4,1 & 3,5 & 3,6 & 5,0 \\
\hline $\begin{array}{l}\text { Mean relative } \\
\text { humidity }(\%)\end{array}$ & 80,6 & 89,2 & 95,8 & 89,0 & 80,1 & 75,3 & 75,2 & 64,1 & 75,2 & 76,8 & 84,8 & 93,1 & 81,6 \\
\hline $\begin{array}{l}\text { Mean cloud } \\
\text { cover }\end{array}$ & 3,0 & 5,1 & 5,2 & 3,9 & 3,5 & 3,6 & 2,7 & 1,9 & 3,0 & 2,1 & 3,3 & 4,9 & 3,5 \\
\hline $\begin{array}{l}\text { Mean } \\
\text { PET }\left({ }^{\circ} \mathrm{C}\right)\end{array}$ & $\begin{array}{l}- \\
18,4\end{array}$ & 16,5 & $\begin{array}{l}- \\
16,6 \\
\end{array}$ & $-12,6$ & $-5,9$ & 0,4 & 3,3 & 3,0 & $-2,1$ & $-2,9$ & $-10,9$ & $\begin{array}{l}- \\
13,7 \\
\end{array}$ & $-7,8$ \\
\hline $\begin{array}{l}2009 \text { Erzurum } \\
\text { Plain }\end{array}$ & 1 & 2 & 3 & 4 & 5 & 6 & 7 & 8 & 9 & 10 & 11 & 12 & $\begin{array}{l}\text { Mean } \\
\text { year }\end{array}$ \\
\hline $\begin{array}{l}\text { Mean } \\
\text { temperature } \\
\left({ }^{\circ} \mathrm{C}\right)\end{array}$ & $\begin{array}{l}- \\
12,3 \\
\end{array}$ & $-3,1$ & $-0,6$ & 4,4 & 10,0 & 14,7 & 17,3 & 17,0 & 12,4 & 8,7 & 1,8 & $-1,1$ & 5,8 \\
\hline $\begin{array}{l}\text { Mean wind } \\
\text { velosity }(\mathrm{m} / \mathrm{s})\end{array}$ & 2,0 & 3,1 & 4,0 & 3,7 & 3,0 & 4,0 & 3,2 & 3,4 & 3,1 & 1,7 & 2,3 & 1,8 & 3,0 \\
\hline $\begin{array}{l}\text { Mean relative } \\
\text { humidity }(\%)\end{array}$ & 82,4 & 84,8 & 73,9 & 64,6 & 61,0 & 65,0 & 60,7 & 50,6 & 53,1 & 62,5 & 75,8 & 84,7 & 68,2 \\
\hline $\begin{array}{l}\text { Mean cloud } \\
\text { cover }\end{array}$ & 3,00 & 5,1 & 5,2 & 3,9 & 3,5 & 3,6 & 2,7 & 1,9 & 3,0 & 2,1 & 3,3 & 4,9 & 3,5 \\
\hline $\begin{array}{l}\text { Mean } \\
\text { PET }\left({ }^{\circ} \mathrm{C}\right)\end{array}$ & $\begin{array}{l}- \\
20,4\end{array}$ & $\begin{array}{l}- \\
11,0\end{array}$ & $-8,7$ & $-3,3$ & 2,9 & 7,9 & 10,8 & 10,3 & 5,4 & 2,0 & $-5,4$ & $-8,1$ & $-1,5$ \\
\hline $\begin{array}{l}2010 \\
\text { Palandoken } \\
\text { Mountain } \\
\end{array}$ & 1 & 2 & 3 & 4 & 5 & 6 & 7 & 8 & 9 & 10 & 11 & 12 & $\begin{array}{l}\text { Mean } \\
\text { year }\end{array}$ \\
\hline $\begin{array}{l}\text { Mean } \\
\text { temperature } \\
\left({ }^{\circ} \mathrm{C}\right)\end{array}$ & $-7,5$ & $-7,4$ & $-4,5$ & $-2,1$ & 3,2 & 10,2 & 14,0 & 14,5 & 12,0 & 2,6 & 1,5 & $-3,4$ & 2,8 \\
\hline $\begin{array}{l}\text { Mean wind } \\
\text { velosity }(\mathrm{m} / \mathrm{s})\end{array}$ & 5,4 & 4,7 & 7,4 & 5,8 & 5,3 & 5,4 & 4,4 & 4,7 & 4,5 & 4,5 & 4,1 & 3,2 & 5,0 \\
\hline $\begin{array}{l}\text { Mean relative } \\
\text { humidity }(\%)\end{array}$ & 92,0 & 98,8 & 92,4 & 97,5 & 95,7 & 80,9 & 76,5 & 64,6 & 56,4 & 90,7 & 48,1 & 74,1 & 80,6 \\
\hline $\begin{array}{l}\text { Mean cloud } \\
\text { cover }\end{array}$ & 5,2 & 5,5 & 4,3 & 4,8 & 4,5 & 2,9 & 2,0 & 1,7 & 1,8 & 4,1 & 0,7 & 2,7 & 3,3 \\
\hline $\begin{array}{l}\text { Mean PET } \\
\left({ }^{\circ} \mathrm{C}\right)\end{array}$ & $\begin{array}{l}- \\
15,2 \\
\end{array}$ & $\begin{array}{l}- \\
15,4\end{array}$ & 13,2 & $-\overline{10,6}$ & $-4,7$ & 2,7 & 7,0 & 7,3 & 4,4 & $-4,8$ & $-7,1$ & 10,4 & $-5,0$ \\
\hline $\begin{array}{l}2010 \text { Erzurum } \\
\text { Plain }\end{array}$ & 1 & 2 & 3 & 4 & 5 & 6 & 7 & 8 & 9 & 10 & 11 & 12 & $\begin{array}{l}\text { Mean } \\
\text { year }\end{array}$ \\
\hline $\begin{array}{l}\text { Mean } \\
\text { temperature } \\
\left({ }^{\circ} \mathrm{C}\right)\end{array}$ & $-4,3$ & $-1,9$ & 3,1 & 5,6 & 10,4 & 15,9 & 19,5 & 20,3 & 17,0 & 9,1 & 1,5 & $-1,9$ & 7,9 \\
\hline $\begin{array}{l}\text { Mean wind } \\
\text { velosity }(\mathrm{m} / \mathrm{s})\end{array}$ & 2,1 & 2,0 & 3,5 & 2,8 & 2,7 & 2,9 & 3,37 & 3,7 & 2,9 & 2,8 & 1,4 & 1,5 & 2,6 \\
\hline $\begin{array}{l}\text { Mean relative } \\
\text { humidity }(\%)\end{array}$ & 84,0 & 82,3 & 69,1 & 71,3 & 69,6 & 60,1 & 56,0 & 44,8 & 48,1 & 70,2 & 66,1 & 76,6 & 66,5 \\
\hline $\begin{array}{l}\text { Mean cloud } \\
\text { cover }\end{array}$ & 5,2 & 5,5 & 4,3 & 4,8 & 4,5 & 2,9 & 2,0 & 1,7 & 1,8 & 4,1 & 0,7 & 2,7 & 3,3 \\
\hline $\begin{array}{l}\text { Mean PET } \\
\left({ }^{\circ} \mathrm{C}\right)\end{array}$ & $\begin{array}{l}- \\
11,6\end{array}$ & $-9,0$ & $-4,6$ & $-1,6$ & 3,7 & 9,4 & 13,2 & 13,7 & 10,3 & 2,3 & $-5,9$ & $-9,2$ & 0,9 \\
\hline
\end{tabular}


Table 3. The deferences between Palandoken Mountain and Erzurum Plain Meteorological Data and PET values (differences between mountain and plain in 2009 and 2010)

\begin{tabular}{|c|c|c|c|c|c|c|c|c|c|c|c|c|c|}
\hline $\begin{array}{l}\text { Parameters } \\
\text { ( Erzurum } \\
\text { Plain } \\
\text { - Palandoken } \\
\text { Mountain) }\end{array}$ & Jan & Feb & Mar & Apr & May & Jun & Jul & Aug & Sep & Oct & Nov & Dec & Year \\
\hline $\begin{array}{l}2009 \text { Mean } \\
\text { Temp. }\left({ }^{\circ} \mathrm{C}\right)\end{array}$ & $-3,1$ & 5,3 & 7,5 & 8,3 & 7,7 & 6,6 & 6,6 & 6,6 & 6,6 & 4,0 & 5,2 & 4,4 & 5,5 \\
\hline $\begin{array}{l}2010 \text { Mean } \\
\text { Temp. }\left({ }^{\circ} \mathrm{C}\right)\end{array}$ & 3,2 & 5,6 & 7,5 & 7,7 & 7,2 & 5,7 & 5,6 & 5,8 & 5,0 & 6,5 & 0,0 & 1,4 & 5,1 \\
\hline $\begin{array}{l}\text { Mean } \\
\text { Temperature } \\
\left({ }^{\circ} \mathrm{C}\right)\end{array}$ & 0,1 & 5,4 & 7,5 & 8,0 & 7,5 & 6,2 & 6,1 & 6,2 & 5,8 & 5,2 & 2,6 & 2,9 & 5,3 \\
\hline $\begin{array}{l}2009 \text { Mean Rel. } \\
\text { Hum. (\%) }\end{array}$ & 1,8 & $-4,5$ & $-22,0$ & $-24,4$ & $-19,1$ & $-10,3$ & $-14,5$ & $-13,5$ & $-22,1$ & $-14,3$ & $-9,0$ & $-8,4$ & $-13,4$ \\
\hline $\begin{array}{l}2010 \text { Mean Rel. } \\
\text { Hum. (\%) }\end{array}$ & $-8,0$ & $-16,5$ & $-23,2$ & $-26,2$ & $-26,2$ & $-20,8$ & $-20,5$ & $-19,9$ & $-8,3$ & $-20,5$ & 18,0 & 2,4 & $-14,1$ \\
\hline $\begin{array}{l}\text { Mean Rel. Hum. } \\
(\%)\end{array}$ & $-3,1$ & $-10,5$ & $-22,6$ & $-25,3$ & $-22,6$ & $-15,6$ & $-17,5$ & $-16,7$ & $-15,2$ & $-17,4$ & 4,5 & $-3,0$ & $-13,7$ \\
\hline $\begin{array}{l}2009 \text { Mean Wind } \\
\left(\mathrm{m} \mathrm{s}^{-1}\right)\end{array}$ & $-4,7$ & $-1,6$ & $-1,5$ & $-2,8$ & $-2,0$ & $-1,3$ & $-1,5$ & $-1,2$ & $-3,8$ & $-2,4$ & $-1,2$ & $-1,8$ & $-2,0$ \\
\hline $\begin{array}{l}2010 \text { Mean Wind } \\
\left(\mathrm{m} \mathrm{s}^{-1}\right)\end{array}$ & $-3,3$ & $-2,7$ & $-4,0$ & $-3,1$ & $-2,6$ & $-2,5$ & $-1,1$ & $-1,1$ & $-1,6$ & $-1,7$ & $-2,8$ & $-1,7$ & $-2,3$ \\
\hline $\begin{array}{l}\text { Mean Wind } \\
\left(\mathrm{m} \mathrm{s}^{-1}\right)\end{array}$ & $-4,0$ & $-2,1$ & $-2,7$ & $-2,9$ & $-2,3$ & $-2,0$ & $-1,3$ & $-1,1$ & $-1,7$ & $-2,1$ & $-2,0$ & $-1,7$ & $-2,2$ \\
\hline $\begin{array}{l}2009 \text { PET } \\
\left({ }^{\circ} \mathrm{C}\right)\end{array}$ & $-1,9$ & 5,5 & 8,0 & 9,3 & 8,8 & 7,5 & 7,5 & 7,3 & 7,5 & 4,9 & 5,4 & 5,6 & 6,3 \\
\hline $\begin{array}{l}2010 \text { PET } \\
\left({ }^{\circ} \mathrm{C}\right)\end{array}$ & 3,6 & 6,4 & 8,6 & 9,0 & 8,4 & 6,7 & 6,2 & 6,5 & 6,0 & 7,0 & 1,2 & 1,2 & 5,9 \\
\hline $\begin{array}{l}\text { Mean PET } \\
\left({ }^{\circ} \mathrm{C}\right)\end{array}$ & 0,84 & 5,98 & 8,3 & 9,13 & 8,57 & 7,08 & 6,86 & 6,89 & 6,71 & 5,98 & 3,25 & 3,36 & 6,1 \\
\hline
\end{tabular}

\section{DISCUSSION}

During winter months, Palandoken PET values have been higher than those of Erzurum plain. However, for the 2009-2010 period, the average PET value for the plain was $-0.3^{\circ} \mathrm{C}$ while the PET value for the mountain was $-6.4^{\circ} \mathrm{C}$. The largest PET difference between Erzurum and Palandoken

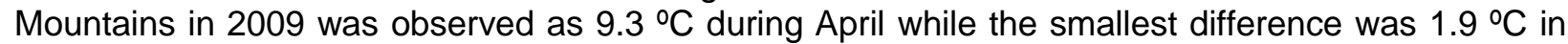
January. In a similar comparison, the largest PET difference between Erzurum and Palandoken Mountains in 2010 was observed as $9.0^{\circ} \mathrm{C}$ during April while the smallest difference was $1.2^{\circ} \mathrm{C}$ in December.

Erzurum Plain is colder than the mountain foot, due to the plain is surrounded by high mountains and its bowl-shaped form. Hence, during the days when air temperature is extremely low, cold weather settles into lowlands; and due to this settling, it is determined that the PET value in Erzurum Plain is lower than the region in Palandoken Mountain that is on the northeastern part of the plain. According to the measurement made in winter month (novadays, measured by car) while the temperature in city center was $-5{ }^{\circ} \mathrm{C}$ at 17 on $5^{\text {th }}$ January 2013 , it was measured as $-23{ }^{\circ} \mathrm{C}$ on the way of airport where is the new development axe of the city. These values show that climate must be considered in the process of mapping new settlement areas. Distinctive topography and different climate features of highlands which gives characteristics to these areas make the highlands attractive in terms of plant diversity and climate.

Climatic parameters such as temperature, humidity, radiation, precipitation and wind are the parameters creating microclimatic areas in the mountainous areas (Chronopoulos et al., 2012; Barry and Chorley, 2001). Highland areas are the places providing different attractive destinations for the tourism and recreation (Ndubisi, 2003; Nepal and Chipeniuk, 2005). Palandöken Mountains in which the study is carried on has become one of the important winter tourism centers of Turkey. Physical 
environment, regional characteristics and thermal comfort conditions of this type of places significantly affect the tourists' decisions (Yilmaz et al., 2009; Lin and Matzarakis, 2008). Therefore, identification of the thermal comfort conditions of the Palandoken Mountains is very important for the tourism.

While the mean temperature of the mountain was $0.3^{\circ} \mathrm{C}$ in 2009 , it was $2.8^{\circ} \mathrm{C}$ in 2010 . Additionally, the mean temperature of the plain, which was $5.8{ }^{\circ} \mathrm{C}$ in 2009 , increase to $7.9{ }^{\circ} \mathrm{C}$ in 2010 . It is considered according to WMO report that 2010 can be accepted as one of reason of this increase, because it is one of the hottest years of the world (WMO, 2011).

The results show that there was a difference in PET values in the magnitude of $6.3 \stackrel{\circ}{\circ}$ between the two locations in 2009 while this difference was $5.9^{\circ} \mathrm{C}$ in 2010 . The difference is due to the fact that 2009 was a colder year than 2010. A more detailed look indicates that, for the above period, the largest difference was in April and the smallest difference in December and January.

There is an altitude difference of $1179 \mathrm{~m}$ between the two stations. It was observed that there was a PET value decline of $0.52{ }^{\circ} \mathrm{C}$ for every $100 \mathrm{~m}$ decline in altitude. This was expected since temperature declines in higher altitudes. As a matter of fact, this value is found in another study as a decrease $0.67^{\circ} \mathrm{C}$ every $100 \mathrm{~m}$ (Onur et al., 2013). And also, the temperature has been shown to fall approximately $0.3^{\circ} \mathrm{C}$ every $100 \mathrm{~m}$ in free atmosphere according to wet adiabatic, and $1^{\circ} \mathrm{C}$ according to dry adiabatic (Fairbridge and Oliver, 2005).

Relative humidity is also the limiting factor for bioclimatic comfort conditions. Humidity factor had decreased from $80 \%$ in 2009 to $67 \%$ in 2010 . In 2009 and 2010, the humidity difference between mountain and plain was $13.7 \%$ and it is observed that humidity ratio is higher in the mountain than plain (Table 3). Differences on the topographical structure and greenhouse gases and emissions released into the atmosphere from urbanized land are the reasons of this difference. When the PET values are analyzed, it is seen that the values in urbanized land are higher. Greenhouse gases, surface radiation, low wind speed and low level of humidity are accepted as the reasons of this situation. In fact, similar results are obtained from many studies analyzing topographic structure and making urban-rural place comparison (Zaninovic et al., 2006; Endler et al., 2010; Kamoutsis et al., 2010; Caliskan et al., 2013). In other words, while rural areas quickly warm up and cool down, it become slowly in urban areas. According to the study made in Greece in summer period, human thermal comfort is analyzed in two different areas and concluded that mountainous areas are more suitable for tourism and recreation (Kamoutsis et al., 2010). When the results of analysis are evaluated, it is observed that while air temperature was $-9.2^{\circ} \mathrm{C}$ on the mountain in winter (January 2009), it was $-12.3^{\circ} \mathrm{C}$ on the plain in the same year (Table 3). Especially in extremely cold period of winter, uncomfortable times are observed on the bowl-shaped plain in accordance with the mountain.

\section{CONCLUSIONS}

Erzurum Plain and the Mountains of Palandoken according to climate data for 2009-2010 were calculated PET. There is an altitude difference of $1179 \mathrm{~m}$ between the two stations. It was observed that there was a PET value decline of $0.5^{\circ} \mathrm{C}$ for every $100 \mathrm{~m}$ decline in altitude. This was expected since temperature declines in higher altitudes. Distinctive topography and different climate features of highlands which gives characteristics to these areas make the highlands attractive in terms of plant diversity and climate.

Since the plain is surrounded by high mountains, during December and January, due to inversion, it is affected negatively in terms thermal comfort. During these months, the Mountain shows a different pattern. The PET value is measured high because of wavy rays and snow reflections in the mountain during these months, while the same comfort cannot be observed in the summer months. This suggests that the slopes are perhaps better and more comfortable in terms of settlement. In addition to ski tourism, one can design winter gardens to improve the attractiveness of the area and bring more domestic tourists in. The local administrators usually promote the flat areas in the plain for development due to cost concerns. The cost of building infrastructure for these areas might be much cheaper. However, the plain has very valuable agricultural land that should not be used for new building projects.

Designers and planners ensure that people should live in comfortable places by taking into account environmental factors. It is important to achieve ecological planning and sustainable land uses categories of environmental factors for the landscape architecture and urban planner. Landforms are 
important for urban planning and landscape architecture because urban comfort depends on them. Land structure and characters bear natural features (farming, mining, forestry etc.) and should be preserved.

\section{ACKNOWLEDGEMENT}

Authors thank to Uğur Avdan (Anadolu University) for preparing Figure 3. Authors thank to Turkish State Meteorological Service (The data was obtained from Erzurum Meteorological Station (1758 m) and Palandoken Mountains Meteorological Station (2973 m) for 2009 and 2010.

\section{REFERENCES}

Ali-Toudert F. and Mayer, H., (2007a). Effects of asymmetry, galleries, overhanging facades and vegetation on thermal comfort in urban street canyons, Solar Energy, 81(6) 742-754.

Ali-Toudert F. and Mayer H., (2007b) Thermal comfort in an east-west oriented street canyon in Freiburg (Germany) under hot summer conditions, Theor. Appl. Climatol., 87, 223-237.

Anderson L.T. (2000) Planning the Built Environment. Planners Press American Planning Association, Chicaco, Illinois, Washington D.C.268pp.

Barry R.J. and Chorley R.J., (2001) Atmosphere, weather and climate. 8 ed., Routledge, Taylor \& Francis Group, London, UK, p. 422

Bates B.C; Kundzewicz Z.W., Wu S., Palutikof J.P. (eds.), (2008) Climate Change and Water. Technical Paper of the Intergovernmental Panel on Climate Change, IPPC Secretariat, Geneva, $210 \mathrm{pp}$.

Caliskan O., Turkoglu N., Matzarakis A., (2013) The Effects of Elevation on Thermal Bioclimatic Conditions in Uludağ (Turkey), Atmosfera, 26(1), 45-57.

Chronopoulos K., Kamoutsis A., Matsoukis A., Manoli E., (2012a) An artificial neural network model application for the estimation of thermal comfort conditions in mountainous regions, Greece, Atmosfera, 25(2) 171-181.

Chronopoulos K.I., Kamoutsis A.P., Matsoukis A.S., (2012b) Thermal comfort estimation in relation to different orientation in mountainous regions in Greece by using artificial neural networks, Global NEST Journal, 14(4) 532-539.

Cohen P., Potchter O., Matzarakis A., (2012). Daily and seasonal climatic conditions of green urban open spaces inthe Mediterranean climate and their impacton human comfort, Building and Environment, 51, 285-295.

Epstein Y. and Moran D.S., (2006) Thermal Comfort and the Heat Stress Indices, Industrial Health, 44, 388-398.

Endler C., Oehler K., Matzarakis A., (2010). Vertical gradient of climate change and climate tourism conditions in the Black Forest, Internainal Journal of Biometeorol., 54, 45-46.

Fanger P.O. (1970) Thermal comfort, Danish Technical Press, Copenhgen.

Farajzadeh H. and Matzarakis A. (2012) Evaluation of thermal comfort conditions in Ourmieh Lake, Iran, Theoretical And Applied Climatology, 107(3-4), 451-459.

Fairbridge W.R. and Oliver J.E. (2005) Lapse rate. In: Encyclopedia of World Climatology (J. E. Oliver Ed.), Springer, Dordrecht, 448-450.

Fröhlich D. and Matzarakis A. (2012) Modeling of changes in thermal bioclimate: examples based on urban spaces in Freiburg, Germany, Theor Appl Climatol., DOI 10.1007/s00704-012-0678-y

Gagge A., Stolwijk A. and Nishi Y. (1971) An effective temperature scale based on a simple model of human physiological regulatory response, ASHRAE Trans, 77, 247-57.

Gaitani N., Mihalakakou G. and Santamouris M., (2007) On the use of bioclimatic architecture principles in order to improve thermal comfort conditions in outdoor spaces, Greece, Building and Environment, 42, 317-324.

Givoni B., Noguchi M., Saaroni H., Pochter O., Yaacov Y., Feller N., (2003) Outdoor comfort research issues, Energy and Buildings, 35(1), 77-86.

Google Google Maps, 2012. Erzurum Google Maps, http://maps.google.com/

Google Google Earth, 2012. Erzurum Google Earth.

Hamilton J. M. and Lau M. A., (2004). The role of climate information in tourist destination choice Decision-making. Centre for Marine and Climate Research, Hamburg University, Hamburg, Germany November 25, Working Paper FNU-56.

Höppe P., (1999). The physiological equivalent temperature-a universal index for the biometeorological assessment of the thermal environment, Int J Biometeorol, 43, 71-75. 
http://www.tsym3.selcuk.edu.tr . it is the web site of Number 106Y130 TUB TAK project of the Formation of $3 \times 3$ Resolution Elevation Model for Turkey supported by Local Elevation Data using SRTM Data

IPCC (2007) Climate change 2007. Impacts, adaptation, and vulnerability. Working group II contribution to the intergovernmental panel on climate change fourth assessment report. IPCC Secretariat, Geneva, pp 1-22.

Johansson E., (2006) Influence Of Urban Geometry On Outdoor Thermal Comfort in A Hot Dry Climate: A Study in Fez, Morocco, Building and Environment, 41, 1326-1338.

Kamoutsis A., Matsoukis A., Chronopoulos K., Manoli E. (2010) A Comparative Study of Human Thermal Comfort Conditions in Two Mountainous Regions in Greece During Summer, Global NEST Journal, 12(4), 401-408.

Kolawole A., (2001). Design for comfort in Nigeria - a bioclimatic approach, Renewable Energy, Nigerya, 23(1) $57-76$.

Lin T.P. and Matzarakis A., (2008) Tourism climate and thermal comfort in Sun Moon Lake, Taiwan, Int. J. Biometeorol., 52, 281-290.

Lin T.P., (2009). Thermal perception, adaptation and attendance in a public square in hot and humid regions, Build. Environ, 44(10), 2017-2026.

Lin T.P., Matzarakis A., (2011) Tourism climate information based on human thermal perception in Taiwan and Eastern China, Tourism Management, 32(3), 492-500.

Lin T.P., Tsai KT, Hwang R.L. and Matzarakis A., (2012). Quantification of the effect of thermal indices and sky view factor on park attendance, Landscape Urban Planning, 107(2), 137-146. http://dx.doi.org/10.1016/j.landurbplan.

Matzarakis A., Mayer H., and Iziomon M.G., (1999). Applications of a universal thermal index: physiological equivalent temperature, Int $J$ Biometeorolo, 43, 76-84.

Matzarakis A., Rutz F., Mayer H., (2007) Modelling radiation fluxes in simple and complex, environments e application of the RayMan model, International Journal of Biometeorology, 51, 323-334.

Matzarakis A., Amelung B., (2008). Physiologically equivalent temperature as indicator for impacts of climate change on thermal comfort of humans. in: Thomson MC et al., (eds) Seasonal forecasts, climatic change and human health. Advances in global change research 30 . Springer, Berlin, 161-172 pp.

Matzarakis A., Rutz F., (2005). Application of RayMan for tourism and climate investigations, Annalen der Meteorologie, 41(2), 631-636.

Matzarakis A. and Gulyas A., (2007). Selected Examples of Bioclimatic Analysis Applying The Physiologically Equivalent Temperature in Hungary, Acta Climatologica Et Chorologica Universitatis Szegediensis, 40-41, 37-46.

Matzarakis A., Rutz F. and Mayer H., (2010) Modelling Radiation fluxes in simple and 371 complex environments: Basics of the RayMan model, Int J Biometeorol, 54, 131-139.

Matzarakis A., Hammerle M., Endler C., Muthers S. and Koch E. (2012) Assessment of tourism and recreation destinations under climate change conditions in Austria, Meteorologische Zeitschrift, 21, 157-165.

Mayer H. and Höppe P., (1987). Thermal comfort of man in different urban environments, Theor. Appl. Climatol, 38, 43-49.

Mishev P. and Mochurova M., (2008) Climate change impacts on tourism. International conference "global environmental change: challenges to science and society in south-eastern Europe" http://global-change.meteo.bg/conference_en.htm 19-21 May 2008, Sofia, Bulgaria.

Nepal K.S. and Chipeniuk R., (2005). Mountain tourism: Toward a Conceptual Framewok, Tourism Geographies, 7, 313-333.

Ndubisi F., (2003) Ecological Planning: A Historical and Comparative Synthesis Foreword by Frederick R. Steiner, Johns Hopkins University Press, 287pp.

Nikolopoulou M., Lykoudis S., (2006). Thermal comfort in outdoor urban spaces: Analysis across different European countries, Build Environ, 41(11), 1455-1470.

Nikolopoulou M., Lykoudis S., (2007) Use of outdoor spaces and microclimate in a Mediterranean urban area, Build Environ, 42(10), 3691-3707.

Perch-Nielsen S.L., (2008). Climate Change and Tourism Intertwined. A dissertation submitted to ETH Zurich for the degree of Doctor of Sciences DISS. ETH No. 17758.

Picot X., (2004). Thermal comfort in urban spaces: Impact of vegetation growth - Case study: Piazza della Scienza, Milan, Italy, Energy and Buildings, 36(4) 329-334. 
Rudel E., Matzarakis A. and Koch E., (2007) Summer Tourism in Austria and Climate Change. in: Oxley, L. and Kulasiri, D. (eds) MODSIM 2007. International Congress on Modelling and Simulation. Modelling and Simulation Society of Australia and New Zealand, December 2007, pp. 19341939. ISBN: 978-0-9758400-4-7.

Scott D., McBoyle G., Schwartzentruber M. (2004). Climate change and the distribution of climatic resources for tourism in North America, Climate Research, 27, 105-117.

Scott D, McBoyle G, Minogue A., Mills B., (2006). Climate change and the sustainability of ski-based tourism in Eastern North America: a reassessment, $J$ Leis Res, 14,376-398.

Thorsson S., Lindberg F., Björklund J., Holmer B. and Rayner D., (2011). Potential changes in outdoor thermal comfort conditions in Gothenburg. Sweden due to climate change: the influence of urban geometry, International Journal of Climatology, 31(2), 324-335.

Toy S. (2010). Evaluation of recreational areas in East Anatolia region for bioclimatic comfort values. Graduate School of Natural and Applied Sciences Ataturk Univ. (unpublished PhD Thesis) Erzurum, $218 \mathrm{p}$.

Toy S., and Yilmaz, S., (2010) Evaluation of 10-year temperature differences between urban and rural ares of a well-planned, unindustrialised and medium - size Turkish town, Erzincan, Journal of Urban Planning and Development (ASCE), 136(4), 349-356.

Unger J, (1999). Comparisons of urban and rural bioclimatological conditions in the case of a CentralEuropean city, Int. Journal of Biometeorology, 43, 139-144.

VDI (1998). Methods for the human-biometeorological evaluation of climate and air quality for urban and regional planning. Part I: Climate. VDI guideline 3787. Part 2. Beuth, Berlin.

WMO (2011) Weather extremes in a Changing Climate: Hindsight on Foresight. WMONo.1075.

Yilmaz S., Demircioglu Yildiz N., Toy S. and Irmak M.A. (2009) The role of climatic elements in public tendency towards alternative tourism and the sample of Turkey, Atmosfera, 22(4), 367-374.

Yilmaz S., Toy S., Irmak M. A. and Yilmaz, H., (2007a) Determination of climatic differences in three different land uses in the city of Erzurum, Turkey, Building and Environment, 42(4), 1604-1612.

Yilmaz S., Toy S., and Yilmaz H. (2007b) Human thermal comfort over three different land surfaces during summer in the city of Erzurum, Turkey, Atmósfera, 20(3), 289-297.

Yilmaz S., Toy S., Yilmaz H., (2010) Determination of the winter human thermal comfort distributions in a ski-centre. 7. BIOMET Conference 12- 14 April 2010 at the Albert-Ludwigs-University Freiburg, Oral presentation, Germany, pp. 370-373.

Zaninovic K., Matzarakis A., Cegnar T., (2006) Thermal comfort trends and variability in the Croatian and Slovenian mountains, Meteorol Z, 15,243-251.

Zaninovic K. and Matzarakis A., (2009) The bioclimatological leaflet as a means conveying climatological information to tourists and the tourism industry, Int $J$ Biometeorol, 53(4), 369-374.

Zhao C., Fu G., Liu X., and Fu F., (2011). Urban planning indicators, morphology and climate indicators: a case study for a north-south transect of Beijing, China Building and Environment, 46(5), 11741183.

Zhang X., Zhong T., Wang K., Cheng Z., (2009). Scaling of impervious surface area and vegetation as indicators to urban land surface temperature using satellite data, Int J Remote Sens, 30(4), 841859.

(http://images.google.com), (http://www.kultur.gov.tr/TR/Genel/rg.ashx?DIL).

http://maps.google.com/ 